\title{
Effects of Financial Attitudes, Financial Behavior, and Financial Literacy to Financial Satisfaction in Women Workers (Case Study of Female Lecturer at Andi Djemma Palopo University)
}

\author{
Erniyati Caronge ${ }^{1}$, Mediaty $^{2}$, Hartina Fattah $^{3}$, Khaeril ${ }^{4}$ \\ \{carongekopertis@yahoo.co.id ${ }^{1}$, mediatyfebuh@yahoo.com², thinafattah@gmail.com ${ }^{3}$, \\ pettalla14@gmail.com $\left.{ }^{4}\right\}$ \\ Universitas Andi Djemma, Makassar ${ }^{1}$, Universitas Hasanuddin, Makassar ${ }^{2}$, STAI Yapnas Jeneponto ${ }^{3}$, \\ STIEM Rutu Nusa Ambon, Indonesia ${ }^{4}$
}

\begin{abstract}
The Financial factors are very important, so we need to think that is used to meet the needs and maintain and develop life. This study tries to provide empirical evidence of the influence of financial attitude, financial behavior, and financial literacy on financial satisfaction in working women. The population of this study were all female lecturers who worked at Andi Djemma University in Palopo City. Sample selection using a census sample in which all populations are sampled. Results of the research indicate that Financial Attitude, Financial Behavior and Financial Literacy, affect Financial Satisfaction both partially and simultaneously.
\end{abstract}

Keywords: Financial attitude, financial behavior, financial literacy and financial satisfaction.

\section{Introduction}

Financial aspects are the main thing and need to think about considered after before you start a family wherein the family the need for money is needed. In this case, the money is used to sustain and improve the standard of living of their families in the future. The Directorate General of the Religious Courts (Supreme Court, Supreme Court, 2010) formally presented divorce data showing that from approximately 285,184 divorce cases in Indonesia handled by a religious court in $2010,67,891$ cases $(23.8 \%$ of the total) divorces were caused by economic reasons or financial aspects. In other words, there are serious problems between married couples regarding financial problems, male or female, which can lead to separation [1].

In addition, it should be noted that what added to the financial aspects and resulting in divorce in the family can also be caused by a lack of education and openness to financial problems, unemployment, and things that are often done by ordinary people. Poor financial management which can leads to losses of income, expensive expenses, unwise decisions, a great desire to spend money. In the end, proper financial management must be done so that family goals and divorce issues can be overcome. The cause of the previous case is due to non-existent knowledge about finance (financial literacy). In addition, some Indonesians rarely consider financial planning; for example, approximately $26 \%$ of Indonesia's population does not plan for the decision, approximately $45 \%$ of doing people pension planning financial but 
with poor management, and approximately $29 \%$ of people do their pension financial planning properly [2].

In Indonesia initially, there were not many articles discussing the level of Financialliteracy of the people Indonesian in the industry financial and the level of Financial Attitude about the reactions of Indonesians to their Financial management, and their concern for Financial Satisfaction and Financial Status. As an individual who is married, the responsibility to overcome economic problems is very important. This is caused by economic problems causing crisis an of trust, quarreling, even divorce and separation, [3]. This is the reason why financial satisfaction is very important. Moreover, research conducted by Rajna, Moshiri and Junid (2011) illustrates that 34.6\% of Malaysian doctors practice exercise financial management that is very profitable, and some of them have positive financial attitudes, but they do not have financial management practices [4].

Financial success is one of the happiness derived from the results of efforts that have been done by someone. The happiness of one's life can be interpreted as the ultimate achievement of the results of whatever effort has been made. The form of happiness that is mostly produced by someone who has made every effort is one of achieving Financial Satisfaction. The origin of Financial Satisfaction can be seen from the behavior of someone who has to do with how someone is able to manage their income to meet the needs of their lives that come financial income. Financial needs are said to be successful if someone has been able to meet short term consumption and long term needs without slightest lack [5].

Hira et al. (1998) claim that financial satisfaction is a test of personal financial management that has achieved success [6]. Moreover, Joo (2008) states that Financial satisfaction reflects the financial condition of a person. People are happy and free from fear due to personal financial circumstances [7]. Praag et al. (2003) proposed Financial Satisfaction, where financial satisfaction is part of the field of satisfaction (satisfaction domain). Domain satisfaction is related to individual satisfaction related to other fields that vary in different ways, such as health, financial condition and type of work. Mugenda and Hira (1998) suggested that satisfaction with life can be pursued by managing money. A good financial manager will provide financial satisfaction, which is one of the triggers for life satisfaction [6].

James and Garrett (2013) noted that financial satisfaction is often seen as the primary goal for financial therapists and financial advisers, and is a factor related to the client's subjective experience and perceptions that should not be ignored [8]. Joo and Grable (2009) describe a conceptual working model that combines sociodemographic characteristics with stress factors, financial attitude and financial knowledge. Financial satisfaction can also arise from a good financial decision-making process based on good financial knowledge [9]. Joo (2008) provides information about financial knowledge that is part of the financial a person's health, along with financial satisfaction and financial attitude [7].

The state of Indonesia's economic growth has been better experienced a positive improvement influence on income growth that has increased. In addition, there are individuals who have different income levels than most people who can be said to be higher and are unable to manage their finance properly and will face problems in supervise finances. What can happen is the inability to be able to pay bills on time, not being able to pay loans, not having an old age program, and no savings; as a result, the financial satisfaction of these individuals is low [5].

One important component of Indonesian society is women, where women are a part that takes many roles in community life, especially in domestic life. The main focus on how to improve women's financial satisfaction in the household where they are one of the main parts 
of the Indonesian community component that greatly family affects welfare but also benefits financial planning and their saving behavior [10]. In addition Kasman et al. (2018) focus more on women who work, because they assume that women who work will face more pressure because they are given the responsibility to be able to balance a professional career in working with the responsibilities of bearing children in the household [11].

From the description of the background of the problems raised, the aim of this study is to determine the effect of financial knowledge, financial attitude, financial behavior, on financial satisfaction.

\subsection{Telic theory}

Praag et al. (2003) illustrate that the satisfaction of the financial theory with the TELIC theory. It was stated that Financial Satisfaction is part of the satisfaction area (satisfaction domain). Domain satisfaction has a relationship with individual satisfaction in various fields of life satisfaction, such as health, financial, and work situations [12]. Pavot and Diener (2008) suggested that satisfaction domain is a cognitive part of well being subjective where well-being subjective is shown from happiness, life satisfaction and other main areas of life, such as work, health and relationships between people [13].

\subsection{Financial Satisfaction}

Joo (2008) suggests that financial satisfaction shows a person's financial condition is good and happy people who are free from the anxiety of personal financial conditions [7]. Mugenda and Hira(1998) argued about, financial satisfaction where financial satisfaction an evaluation of the satisfaction of each individual on financial, personal conditions [6].

Draughn el at. (1994) argued that economic satisfaction consists of three components, wherein these components are: (1) financial adequacy related to the sufisiency of revenue to satisfy the needs for economic survival, (2) economic welfare that can be felt, is part of a assessment subjective of economic viability, and (3) satisfaction with the level of life which is a perception of the viability of individuals to meet financial demands [14]. Ju and Lown (1992) explain that financial satisfaction is an assessment of the between difference an actual financial condition and an actual financial condition. Very little distinguishes between true desire and financial circumstances. Where is known that the more financial desires that can be achieved, the higher the financial satisfaction [15].

Mugenda and Hira (1998) clarify about the financial satisfaction can be assessed by several things such as (a) saving, (b) debt, (c) the state of finances at this time, (d) the ability to be able to suit g Uhi long-term needs, (c) funds for emergencies, (6) skills in financial management [6].

\subsection{Financial Attitude}

Financial attitude is defined as an individual's tendency towards financial problems they face. It is the ability to be able to plan for future-forward and keep track of the savings account is pitch important. The financial attitude thing is this, which is the size of the state of thoughts, opinions and judgments concerning finances [16]. Financial attitude defined as beliefs and feelings about the regulation of the money they have (Falahati and Paim, 2011).

According to Parotta and Johnson (1998), financial attitude is a perception of the importance of carrying out activities related to finance [17]. Chandra and Mamarista (2015) 
suggested that financial attitude will affect the financial situation of individuals that can increase or decrease financial satisfaction [18]. Attitudes direct to behavior will lead to the level of assessment that will support or not the behavior carried out [19]. Financial attitude is the feelings, thoughts and tendencies of individuals to specific aspects that are at the very visible, both unpleasant and pleasant, toward objects, people, and events [4].

Herdjiono and Damanik (2016) suggested about the existence of a connection between financial attitude and level of financial problems. Thus it can be said that a person's financial attitude also has an impact on how individuals to regulate their financial behavior. Financial attitude can be reflected by the following 6 drafts: 1 . Obsession leads to an individual's paradigm about money and his assumptions about the future to manage finances well. 2 . Power, which refers to individuals who use money as a tool to manage others and according to them money can solve problems. 3. The effort refers to individuals who feel worthy of having money from what they have done. 4. Inadequacy refers to individuals who will always feel they don't have enough money 5 . Retention refers to individuals who have a tendency not to want secrete money 6 . Safety leads to very traditional individual views about money, such as the assumption that money is better saved only without saving at the bank or for investment [20].

\subsection{Financial Behavior}

Xiao (2008) states that financial behavior can be said to be human behavior related to financial management [21]. Hilgerth et al. (2003), financial behavior is a composite of flow cash management, management debt, savings, and investment [22]. Dwinta and Ida (2010) explain that financial behavior is related to responsibilities one's regarding financial management. Effective financial management is setting like a budget, assessing the need to purchase, and debt retires within debt a reasonable time period. Individuals need financial knowledge to create the judgment that will repair the grade of life's future and in the now. Personality behavior reflects the knowledge of application [22].

Atkinson and Messy (2012) explain that there are four questions that will make people give more information and statements about their behavior. The statement includes (1). statement concerning the consideration of making a purchase, which relates elated to whether someone has the ability to pay for his potential purchase. (2)Statements relating to whether respondents normally pay their debts on time. (3), a statement relating to how often the respondent examined the notes connect to financial matters. (4), Representation connect to longterm plan, in which case whether the respondent sets longterm financial goals and how efforts are made to achieve them [23].

Hira et al. (1998) suggested that financial behavior can be interpreted as a personality attitude and behavior in manage they're financial. Where financial behavior is related to spending and savings which are used as benchmarks in investigatigation [6]. Nababan et al. (2012) reported financial behavior relational to how people treat, manage, and use available financial resources [24]. Perry and Morris (2005), Grable et al. (2009), and Kholilah and Iramani, (2013) measure Financial behavior by things several: (a) expenses, (b) bill payments, (c) financial planning, (d) providing money for yourself and family, (e) savings [9], [25], [26]. Indicators of financial behavior variables assessed from the results of research Nababan and Sadalia (2012), namely [24]:

1. Pay bills on time

2. Make an expenditure and expenditure budget

3. Record expenses 
4. Providing funds for unexpected expenses (emergency funds)

5. Saving periodically/regularly

6. Comparing prices between stores/supermarkets/supermarkets before deciding to make a purchase.

\subsection{Financial Literacy}

As per the ASIC 2004 report, it has been recognized that throughout the world that financial literacy financial literacy is a major part of economic and financial stability and development. Understanding financial literacy is still not entirely clear, where financial literacy has many definitions in several existing studies. This is because financial literacy officials give freedom to researchers, thus making researchers/writers free to express and analyze financial literacy [27]. Financial literacy, financial education and financial knowledge can be used interchangeably and have the same meaning and become the subject of debate by Al-Tamimi et al. (2009), Howlett, et al (2008) and Yoong et al. (2012) [28]-[30]. In contrast to what was stated earlier, Huston (2010) argues that financial education and financial knowledge are only two dimensions of financial literacy and therefore, financial literacy can exceed both of these [31]. Anthes (2004) stated about the understanding of the elaborative financial literacy of individuals as the ability to be able to know, analyze, manage, and inform about financial conditions that play a role in the financial ability of the individual itself [32].

The OECD (2013) explains financial literacy as a composite of one's abilities, behaviors, awareness, attitudes and knowledge needed to create good financial decisions and lead to the achievement of financial well-being. From this, it can be defined that three important determinants for testing financial literacy are (1) financial literacy, (2) Financial behavior and (3) Financial Attitude [33]. It is important to know that financial literacy is a composite of knowledge, attitude and behavior, so it is true that exploring these three components in research can be done [23]. Financial literacy is divided into five aspects consisting of basic financial knowledge, saving and credit, insurance, and investment (Chen et al., 1998). From the previous description, it can be described the relationship between financial attitude, financial behavior, financial literacy on financial satisfaction [34].

\subsection{Financial Attitude dan Financial Satisfiction}

Halim and Astuti (2015) argued, if a good financial attitude will affect to good financial management, this is because individuals will have the desire to save, invest, and do financial planning for a better future. Individuals can make money as a very valuable thing and make someone to be responsible and caused a person to have good finances and can improve the quality of life so that it will encourage increased financial satisfaction on the individual [35]. Chandra and Memarista (2015) conducted research on Petra students in Indonesia and able to find a positive relationship between financial attitudes and financial satisfaction [18].

\subsection{Financial Behavior dan Financial Satisfaction}

There is research that has been done before shows the relationship between financial behavior that has an influence on financial satisfaction. The investigation, in which a model was developed by Investigation, was used to predict the level of financial satisfaction between individuals activity in Malaysia. The research results, financial planning and the primary behavior of management finances are a major part of financial satisfaction. The results of the 
study Grable, Park, and Joo, (2009) explain that almost all respondents with low levels of financial satisfaction are not ready to set the concept and more modern financial behavior. Using the two variables, behavioral of financial behavior and self-evaluation of financial behavior [9], conducted by (Xiao et al. 2006) where they suggested that the two variables behavioral have a relationship positive with financial satisfaction among a sample of consumers who use credit counseling services [36].

Another investigation by Xiao et al. (2009) suggested that fiscal behavior has a positive effect on financial satisfaction and financial attitude and, in turn, has an effect on student life satisfaction [37]. In addition, research conducted by Robb and Woodyard (2011) found how (1). save emergency funds, (2). have credit data, (3). not taking excessive funds, (4). credit card payments, (5) have a retirement account, and (6) the skills to manage financial risk, as the six best financial practices in their research using data taken from The Financial Industry Regulatory Authority (FINRA). From their research, they found a positive relationship between these six best fiscal practices and fiscal satisfaction. This research is also in line with the research conducted Ünal and Düger (2015), where they found a relationship between financial behavior that has a positive influence, such as the practice of saving and investing has on fiscal satisfaction [38].

\subsection{Financial Literacy dan Financial Satisfaction}

Financial literacy is a very necessary part of one's fiscal ability to achieve financial success. In standard economic theory, consumers who have complete information and are able to choose and rational in carrying out long term planning financial to maximize utility during their lifetime are consumers who have good financial literacy. However, empirical investigations illustrate that respondents who do not have full information, cannot make rational choices when information is available, so they do not have good financial literacy [39], [40]. Low fiscal literacy has been found by researchers in the USA, as has been done by (Bernheim 1998; Hilgert et al. 2003; Mandell 2008; Lusardi 2010) [22], [41]-[43] and other countries [33]. Many financial education programs have been developed to be able to improve public fiscal literacy [44]. The opinion of some researchers is to suggest that financial literacy has a positive effect on fiscal capability, which results in financial satisfaction [45].

Financial literacy can be assessed properly; this assessment can be done objectively or subjectively. Subjective measurement based on the consumer's assessment self of the level of knowledge their about the realm of life-related to finance. Whereas objective measurement is usually done with a knowledge quiz with questions about certain areas of life. Both types of knowledge may have different impacts on behavior and ability [46]. In this article, financial literacy and financial knowledge are used as a way to be able to change even though there are small differences between the two terms. Previous research has shown that both types of knowledge have a positive influence on financial behavior but the magnitude of the effect is different [47], [48].

\section{Research Methodology}

This research was conducted to women workers who work as lecturers and focused at Andi Djemma University, who have criteria as permanent lecturers of the foundation (DTY) and Hired Lecturer (DPK). 
The population in this study included all-female college teachers working at Andi Djemma University who were qualified as permanent foundation lecturers (DTY), and 67 lecturers were employed. This study uses a census sampling technique in which the researcher takes all members of the population into a sample of 67 samples.

The data analysis model used is multiple linear regression. Where multiple linear regression analysis is performed to determine the direction of the influence of independent variables on the variable dependent, whether partially or even simultaneously. Where independent variables can have a positive or negative effect on the dependent variable. And also to predict the value of the dependent_variable where if the value of the independent variable has upward or mitigate. Multiple linear regression analysis in this study using the software. The formula for multiple linear regression according to (Suprayitno and Sapar, 2012; 77) as follow:

Which in,

$$
\mathrm{Y}=\mathrm{a}+\mathrm{b}_{1} \mathrm{x}_{1}+\mathrm{b}_{2} \mathrm{x}_{2}+\mathrm{b}_{3} \mathrm{x}_{3}+
$$

$$
\begin{array}{ll}
\mathrm{Y} & =\text { Financial_Literacy } \\
\mathrm{A} & =\text { Konstanta } \\
\mathrm{X}_{1} & =\text { Financial_Attitude } \\
\mathrm{X}_{2} & =\text { Financial_Behavior } \\
\mathrm{X}_{3} & =\text { Financial_Literacy } \\
\mathrm{b}_{1}, \mathrm{~b}_{2}, \mathrm{~b}_{3} & =\text { KoefisienRegresi } \mathrm{X}_{3} \\
\mathrm{e} & =\text { Standar Error }
\end{array}
$$

\subsection{Types and Sources of Data}

The type and source of data used in this investigation is to use data primary, data taken directly from the research. object or respondent, both individuals and groups. This data was collected using instruments in the form of questionnaires or interview material, which contained several questions given to respondents.

\subsection{Definition and Measurement of Research Variables}

(i) Independent Variable (Independent, X1)

The independent variable is a variable that is thought to influence the variable dependent. Where dependent variables are also known as a predictor variable or commonly called an independent variable [49]. In addition, independent variables are often referred to as influencing variables, predictor variables, independent variables or independent variables. In this study, the variables used are as follows:

a. Financial Attitude as an independent variable (X1)

Financial Attitude is a person's feelings, thoughts and inclinations towards something that is seen, both pleasant and unpleasant, against an object, personality, and event [4]. Financial attitude can be reflected by the following six concepts: (1) Obession, (2) Power, (3) Effort, (4) Inadequacy, (5) Retention and the last (6) Security. This variable consists of 6 indicators with each indicator consisting of three questions answered using a Likert scale of 1 to 5 points.

b. Financial Behavior as an independent variable (X2)

Financial Behavior is a person's feelings, thoughts and tendencies against specific aspects that are most visible, both unpleasant and pleasant, to objects, individuals, 
and events [4]. Indicators of variables financial behavior measured based on the opinion of Nababan and Sadalia (2012), namely [24]:

1. Pay bills on time

2. Make an expenditure and expenditure budget

3. Record expenses

4. Providing funds for unexpected expenses (emergency funds)

5. Saving periodically/regularly

6. I was comparing prices between stores/supermarkets/supermarkets before deciding to make a purchase.

This variable consists of 6 indicators with each indicator consisting of three questions answered using a Likert scale of 1 to 5 points.

c. Financial Literacy as an independent (X3)

The OECD (2013) 5 defines Financial Literacy as a composite of the skill, behaviors, awareness, attitude and knowledge of individuals needed to make sound financial judgment lead that to the achievement of financial well being. Financial Literacy is divided into five aspects consisting of 1 . basic financial knowledge, 2. Savings and loans (saving and borrowing), 4. Protection (insurance), and 5. investment [33]. These variables consist of 5 indicators, with each indicator consisting of three questions answered with 1 to 5 points.

(ii) The dependent variable (Y)

The dependent variable (Y) is the main variables, which is the researcher's attraction or focus. The dependent variable is also known as the standard or benchmark variable. The dependent variable, or commonly known as the dependent variable in this study, is Financial satisfaction. Hira and Mugenda (1998) argued Financial satisfaction is an assessment of the level of satisfaction of each individual on personal financial conditions [6]. Indicators of financial Satisfaction are 1. Total savings balance 2. Total income 3. Ability to buy goods 4 . Ability to spend monthly [18].

\section{Result and Discussion}

\subsection{Equation and Calculation of Regression Coefficient}

Testing independent variables consisting of financial attitude, financial behavior and financial literacy, on the dependent variable and see if it significantly influences financial satisfaction, multiple regression analysis used. This results of data processing can be seen in the following table:

Table 1. Calculation Results from The Regression Coefficient

\begin{tabular}{|c|c|c|c|c|c|}
\hline \multirow[t]{3}{*}{ Model } & \multicolumn{4}{|c|}{ Coefficients $^{\mathbf{a}}$} & \multirow[b]{3}{*}{ Sig. } \\
\hline & \multicolumn{2}{|c|}{ Unstandardized Coefficients } & \multicolumn{2}{|c|}{$\begin{array}{l}\text { Unstandardized } \\
\text { Coefficients }\end{array}$} & \\
\hline & B & Std.Error & Beta & $\mathrm{t}$ & \\
\hline 1 (Constan) & 5.942 & 6.064 & & .980 & .331 \\
\hline FA & .071 & .114 & .090 & .623 & .536 \\
\hline FB & .001 & .092 & .001 & .010 & .992 \\
\hline FL & .776 & .137 & .747 & 5.673 & .000 \\
\hline
\end{tabular}

a.Dependent Variable: FS 
Based on the results of data processing in the table above, the regression equation is formed:

$$
\mathrm{Y}=5.942+0.071 \mathrm{X}_{1}+0.001 \mathrm{X}_{2}+0.776 \mathrm{X}_{3}+\mathrm{e}
$$

This shows the model that the regression coefficient yield the estimated financial attitude variable is positive (0.071). These results illustrate lest there is a positive influence of financial attitude variables on financial satisfaction, which means that the higher level of financial attitude, the higher effect on financial satisfaction. It may be explained that the financial attitude variable has a positive regression coefficient of 0.071 , which means that if the financial attitude increases by $1 \%$ then financial satisfaction will also increase by $0.071 \%$.

In addition, the above design indicates that the regression coefficient results in the estimated financial behavior variables are positive (0.001). These results illustrate that there is positive influence of financial behavior variables on financial satisfaction, which means that the higher the level of financial behavior, the higher the effect on financial satisfaction. It can be explained that the financial behavior variable has a positive regression coefficient of 0.001 , which means that if financial behavior increases by $1 \%$, financial satisfaction will also increase by $0.001 \%$.

In addition, the above model provides information that the regression coefficient results in the estimated financial literacy variable is positive $(0.776)$. These results illustrate there, there is a positive influence of fiscal literacy variables on fiscal satisfaction, means which that if financial literacy has increased the effect on financial satisfaction will also increase. From the model above the financial literacy variable has an influence and a positive value of 0.776 . This means that if financial literacy has increased by $1 \%$, then financial satisfaction will also increase by $0.776 \%$.

\subsection{Effect of financial attitude on financial satisfaction}

From the regression yield test above, it can be below the influence of fiscal attitudes toward financial_satisfaction and researchers can conclude that financial attitude a positive has an effect on financial satisfaction. These yield are in line with research from, Chandra and Memarista (2015) [18]. Research conducted on Petra students in Indo and testimony establish of a positive relationship between fiscal behavior and fiscal satisfaction.

\subsection{Effect of financial behavior to financial Satisfaction}

From the results of the previous analysis, it be can seen the Financial_Behavior has a positive influence on Financial Satisfaction; this is in line with several previous studies. Research that is in line with the results of the analysis is a research conducted by Xiao et al. (2009), researchers establish that Financial behavior has a positive effect and contributes to Financial Satisfaction and Financial Attitude, in turn, affects student satisfaction [37]. In addition, The Fiscal Industry Regulatory Authority (FINRA), a National of Study National Financial Capability. They establish a relationship positive between the six best financial practices and Financial Satisfaction. In addition, this is in line with the study hold by Ünal and Düger, (2015) the yield of the study establish a positive between influence Financial behavior and financial satisfaction, and this was seen in the practice of saving and investing [38]. 


\subsection{Effect of financial literacy on financial satisfaction}

The yield of the analysis that has been done, it can be seen there that is a positive effect between financial literacy on financial satisfaction. There is also in line with several previous studies. One of the studies that his findings found was that there was an influence between financial literacy and financial satisfaction wherein financial literacy was positively related to financial capability, which in turn yield financial satisfaction [45]. Likewise with Robb and Woodyard (2011) and Xiao et al., (2011) research yield represent that second types of knowledge have a impact positive on financial behavior, but the magnitude of the effect is different [47], [48].

\subsection{Simultaneous Test (F test)}

The test to be carried out is the F examine or simultaneous; this examines carried out to discover out how much influence of the three independent variables on the dependent variable together. In this case, the effect of financial attitude, financial behavior and financial literacy to financial satisfaction has used the analysis of variance (Anova).

Table 2. Hypothesis Testing Results

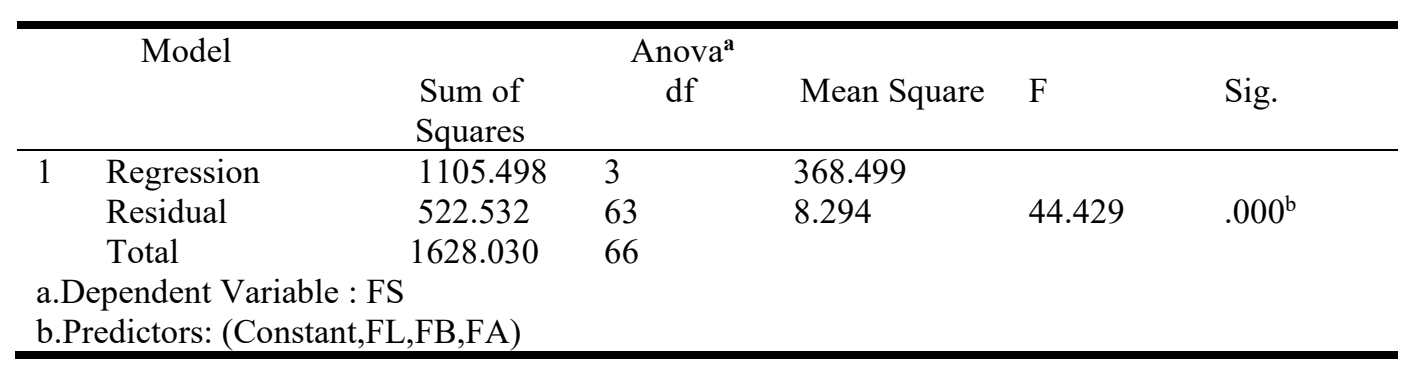

Based on the data in the table above, where the Fhit value of the $X$ variable is 44.442 and significant is 0.00 . Then from Ftab at $95 \%$ confidence level $(n \mathrm{k} ; \mathrm{n}-\mathrm{k})(3 ; 67-4=63)$, the value of Ftab $=2.76$ is obtained. Because Fhit is greater than Ftab, then a degree of error of $5 \%(\alpha=$ 0.05 ) can be said that simultaneous financial attitude, financial behavior, financial literacy has a significant effect on financial satisfaction.

\subsection{Determination Coefficient Analysis}

The next test carried out is the coefficient of determination examine. From the yield of data processing obtained the coefficient of determination of the variables independent Financial attitude, financial behavior and, financial literacy on the variable dependent, namely financial satisfaction are as follows: 
Table 3. Model Summary

\begin{tabular}{|c|c|c|c|c|}
\hline Model & R Squar & $\begin{array}{c}\text { Adjusted R } \\
\text { Square }\end{array}$ & $\begin{array}{l}\text { Std.Error } \\
\text { of the } \\
\text { Estimate }\end{array}$ & $\begin{array}{l}\text { Durbin } \\
\text { Watson. }\end{array}$ \\
\hline $\begin{array}{l}1 \\
\text { a. Predictors: (Constant,FL,FB,FA) } \\
\text { b. Dependent Variable : FS }\end{array}$ & .679 & .664 & 2.880 & 2.555 \\
\hline
\end{tabular}

In the table above, it can be seen the coefficient determination of financial attitude, financial behavior and financial literacy variables on financial satisfaction of 0.679 (R square value), which means that the attitude, financial behavior and financial literacy contributed variables or influenced financial satisfaction by $67.9 \%$, and $32.1 \%(100 \%-67.9 \%)$ were factors Other factors that influence financial satisfaction but not examined in this study.

\section{Conclusion}

Based on the yield of data analysis has that been past previously, the researcher can conclude that among the variables independent consisting of financial attitude, financial behavior and financial literacy on the dependent variable in this case financial satisfaction, a positive effect This means that the higher the financial attitude, financial behavior and financial literacy than the higher the financial satisfaction.

These findings indicate that financial satisfaction can be improved, especially among women workers, if supported by fiscal attitude, fiscal behavior, and financial literacy, which is owned by a working woman in managing her finances in daily life.

Women who are part of households that have a role in managing household finances are expected to be able to increase financial satisfaction and increase their sense of responsibility in managing finances.

Future research is expected to be able to add respondents from other big cities, and from women workers who are varied in order to know and prove how much financial attitude, financial behavior, financial literacy affect financial satiscation.

In addition, this research should be conducted to the management of business units, especially Micro, Small and Medium Enterprises (MSMEs), in order to find out the shortcomings and what can be done to achieve financial satisfaction at MSMEs which are the main foundation of the economy.

\section{References}

[1] Supreme Court.: Laporan Mahkamah Tahunan 2010. Mahkamah Agung Republik Indonesia. p. 77 (2010).

[2] Citibank Indonesia.: Citi Indonesia launches 'Managing Your Wealth. (2014).

[3] Vitz E. B.: Orality and performance in early French romance. Boydell \& Brewer (1999).

[4] Rajna. A, Sharifah E.W, Syed. A. J, and Moshiri. H.: Financial management attitude and practice among the medical practitioners in public and private medical service in Malaysia. International Journal of Business and Management. vol. 6, no. 8, pp. 105, (2011).

[5] Arifin. A. Z.: Influence factors toward financial satisfaction with financial behavior as 
intervening variable on Jakarta area workforce. European Research Studies Journal. vol. XXI (2018)

[6] Hira. T. K and Mugenda. O. M.: Predictors of financial satisfaction: Differences between retirees and non-retirees. Journal of Financial Counseling and Planning. vol. 9, no. 2, pp. 75 (1998).

[7] Joo. S.: Personal financial wellness. In Handbook of consumer finance research, Springer.pp. 21-33 (2008).

[8] Scott, Garrett, and R. James III. Financial ratios and perceived household financial satisfaction. Journal of Financial Therapy. vol. 4, no. 1, pp. 4 (2013).

[9] Grable. J. E, Park. J, and Joo. S.: Explaining financial management behavior for Koreans living in the United States. Journal of Consumer Affairs. vol. 43, no. 1, pp. 80-107 (2009).

[10] Rai. K, Dua. S, and Yadav. M.: Association of Financial Attitude, Financial Behaviour and Financial Knowledge Towards Financial Literacy: A Structural Equation Modeling Approach. FIIB Business Review. vol. 8, no. 1, pp. 51-60 (2019).

[11] Kasman. M, Heuberger. B, and Hammond. R. A.: Recommendations for improving youth financial literacy education. The Bookings Institution: Washington, DC (2018).

[12] Van Praag C. M.: Business survival and success of young small business owners. Small business economics. vol. 21, no. 1, pp. 1-17 (2003).

[13] Pavot. W and Diener. E.: The satisfaction with life scale and the emerging construct of life satisfaction. The journal of positive psychology. vol. 3, no. 2, pp. 137-152 (2008).

[14] Draughn. P. S, LeBoeuf. R. C, Wozniak. P. J, Lawrence. F. C, and Welch. L. R.: Divorcees' economic well-being and financial adequacy as related to interfamily grants. Journal of divorce \& remarriage. vol. 22, no. 1-2, pp. 23-35 (1994).

[15] Lown. J. M and Ju. I. S.: A model of credit use and financial satisfaction. Financial Counseling and Planning. vol. 3, no. 1, pp. 105-124 (1992).

[16] Pankow. J and Knight. K.: Asociality and engagement in adult offenders in substance abuse treatment. Behavioral sciences \& the law. vol. 30, no. 4, pp. 371-383 (2012).

[17] Parrotta. J. L and Johnson. P. J.: The impact of financial attitudes and knowledge on financial management and satisfaction of recently married individuals. Journal of Financial Counseling and Planning. vol. 9, no. 2, pp. 59 (1998).

[18] Chandra. J. W and Memarista. G.: Factors Affecting Financial Satisfaction on Students of Kristen Petra University. Finesta. vol. 3, no. 2, pp. 1-6 (2015).

[19] Ajzen. I. The theory of planned behavior. Organizational behavior and human decision processes. vol. 50, no. 2, pp. 179-211 (1991).

[20] Herdjiono. I and Damanik. L. A.: Pengaruh financial attitude, financial knowledge, parental income terhadap financial management behavior. Jurnal Manajemen Teori dan Terapan| Journal of Theory and Applied Management. vol. 9, no. 3 (2016).

[21] Xiao. J. J.: Applying behavior theories to financial behavior. In Handbook of consumer finance research, Springe. pp. 69-81 (2008).

[22] Hilgert. M. A, Hogarth. J. M, and Beverly. S. G.: Household financial management: The connection between knowledge and behavior. Fed. Res. Bull. vol. 89, pp. 309 (2003).

[23] Atkinson. A and Messy. F.A.: Measuring financial literacy: Results of the OECD/International Network on Financial Education (INFE) pilot study. OECD (2012).

[24] Nababan and Sadalia. I.: Analysis of Personal Financial Literacy and Financial Behavior of Bachelor Students. University of North Sumatra (2012).

[25] Perry. V. G and Morris. M. D.: Who is in control? The role of self-perception, knowledge, and income in explaining consumer financial behavior. Journal of consumer affairs. vol. 39, no. 2, pp. 170-184 (2005)

[26] Kholilah. N. A and Iramani. R.: Financial Management Behavior Studies on Surabaya's Society. Journal of Business and Banking. vol. 3, no. 1, pp. 69-80 (2013).

[27] Remund. D. L.: Financial literacy explicated: The case for a clearer definition in an incr. easingly complex economy. Journal of consumer affairs. vol. 44, no. 2, pp. 276-295 (2010).

[28] Al-Tamimi and Hassan. H. A.: Financial literacy and investment decisions of UAE investors 
The Journal of Risk Finance. vol. 10, no. 5, pp. 500-516 (2009).

[29] Howlett. E, Kees. J, and Kemp. E.: The role of self-regulation, future orientation, and financial knowledge in long-term financial decisions. Journal of Consumer Affairs. vol. 42, no. 2, pp. 223-242 (2008).

[30] Yoong F. J, See. B. L, and Baronovich. D.L.: Financial literacy key to retirement planning in Malaysia. J. Mgmt. \& Sustainability. vol. 2, p. 75 (2012).

[31] Huston. S. J.: Measuring financial literacy. Journal of Consumer Affairs. vol. 44, no. 2, pp. 296$316(2010)$.

[32] Anthes. W. L.: Frozen in the headlights: The dynamics of women and money. Journal of Financial Planning. vol. 13, no. 9, pp. 130-142 (2004).

[33] OECD . L.: Measuring Financial, "Financial literacy and inclusion: Results of OECD/INFE survey across countries and by gender. Financial Literacy \& Education, Russia, jun (2013).

[34] Chen. H and Volpe. R. P.:An analysis of personal financial literacy among college students. Financial services review. vol. 7, no. 2, pp. 107-128 (1998).

[35] Halim. Y. K. E Astuti, Dewi.: Financial Stressors, Financial Behavior, Risk Tolerance, Financial Solvency, Financial Knowledge, dan Kepuasan Finansial. Jurnal manajemen. vol. 3, no. 1, pp. 19-23 (2015).

[36] Xiao. J. J, Sorhaindo. B and Garman. E. T.: Financial behaviours of consumers in credit counselling. International Journal of Consumer Studies. vol. 30, no. 2, pp. 108-121 (2006).

[37] Xiao. J. J, Tang. C, and Shim. S.: Acting for happiness: Financial behavior and life satisfaction of college students. Social indicators research. vol. 92, no. 1, pp. 53-68 (2009).

[38] Ünal. S and Düger. Y. S.: An empirical analysis on the relation between academics' financial well-being and financial behavior. The International Journal of Economic and Social Research. vol. 11, no. 1, pp. 213-227 (2015).

[39] De Meza. D, Irlenbusch. B, and Reyniers. D.: Financial capability: A behavioural economics perspective. Consumer research. vol. 69, pp. 192-193 (2008).

[40] Campbell. J. Y, Jackson. H. E, Madrian. B. C, and Tufano. P.: Consumer financial protection. Journal of Economic Perspectives. vol. 25, no. 1, pp. 91-114 (2011).

[41] Bernheim. D.: Financial illiteracy, education and retirement saving. In Living with defined contribution pensions. University of Pennsylvania Press. Philadelphia. pp. 36-68 (1998).

[42] Mandell. L.: Financial literacy of high school students. In Handbook of consumer finance research. Springer. pp. 163-183 (2008).

[43] Lusardi. A.: Americans' financial capability, Repo rt Prepared for the Financial Crisis Inquiry Commission. Retrieved January. vol. 9, p. 2014 (2010).

[44] Fox. J. J and Bartholomae. S.: Financial education and program evaluation. In Handbook of consumer finance research. Springer. pp. 47-68 (2008).

[45] Xiao. J. J,Chen. C, and Chen. F.: Consumer financial capability and financial satisfaction. Social indicators research. vol. 118, no. 1, pp. 415-432 (2014).

[46] Ellen. P. S.: Do we know what we need to know? Objective and subjective knowledge effects on pro-ecological behaviors. Journal of Business Research. vol. 30, no. 1, pp. 43-52 (1994).

[47] Robb. C. A and Woodyard. A.: Financial knowledge and best practice behavior. Journal of Financial Counseling and Planning. vol. 22, no. 1 (2011).

[48] Xiao. J. J, Tang, J. Serido, and Shim. S.: Antecedents and consequences of risky credit behavior among college students: Application and extension of the theory of planned behavior. Journal of Public Policy \& Marketing. vol. 30, no. 2, pp. 239-245 (2011).

[49] Chandrarin. G.: Metode riset akuntansi pendekatan kuantitatif. Salemba Empat: Jakarta (2017). 